\title{
Two Particularly Evolutionary Loci of trnL-ndhJ of cpDNA of Yulania Baotaina, a New Species (Magnoliaceae) from China
}

\author{
Da-Li Fu ${ }^{1,4}$, Qun Zhang', Min Xu ${ }^{3}$, Dao-Shun Zhou ${ }^{1,4}$, Yue Qin ${ }^{1,4}$, , Yin-Meng Li ${ }^{2}$ \\ ${ }^{1}$ Non-timber Forestry Research and Development Center, Chinese Academy of Forestry, Zhengzhou, China \\ ${ }^{2}$ Dali Yongping Jinguangsi Provincial Nature Reserve Bureau, Yongping, China \\ ${ }^{3}$ Forestry Investigation and Planning Institute of Xizang Autonomous Region, Lasa, China \\ ${ }^{4}$ Key Laboratory of Non-timber Forest Germplasm Enhancement \& Utilization of National Forestry and Grassland Administration, Zhengzhou, \\ China
}

Email address:

fu_dali@163.com (Da-Li Fu), qinyue870711@163.com (Yue Qin)

${ }^{*}$ Corresponding author

\section{To cite this article:}

Da-Li Fu, Qun Zhang, Min Xu, Dao-Shun Zhou, Yue Qin, Yin-Meng Li. Two Particularly Evolutionary Loci of trnL-ndhJ of cpDNA of Yulania Baotaina, a New Species (Magnoliaceae) from China. American Journal of Agriculture and Forestry. Special Issue: The New Evolutionary Theory \& Practice. Vol. 7, No. 5, 2019, pp. 229-233. doi: 10.11648/j.ajaf.20190705.19

Received: August 30, 2019; Accepted: September 16, 2019; Published: September 23, 2019

\begin{abstract}
The partial sequence of $t r n \mathrm{~L}-n d h \mathrm{~J}$ of chloroplast genome ofthe new species of the genus Yulania Spach of Magnoliaceae, Yulania baotaina D. L. Fu, Q. Zhang et M. Xu, collected from Baotai Mountain of Yongping County of Yunnan province of China, and the similar species, Y. campbellii (Hook. f. et Thoms.) D. L. Fu, collected from Yongping and Gongshan county of Yunnan, and Yadong county of Xizang, were amplified and sequenced respectively, which were compared with 39 samples of the chloroplast complete genomes of Magnoliaceae in the NCBI (National Center for Biotechnology Information, USA) database. The results indicated that Y. baotaina has two PEL (particularly evolutionary loci): $\operatorname{trnL}-n d h \mathrm{~J}$ (...TTTCATTTCGGAATTTCCTATTTTCTT...) not possessed by others, and the oppositely evolutionary loci of transversions $t r n \mathrm{~L}-n d h \mathrm{~J}$ (...TTTCATTTCTGAATTTCATATTTTCTT...) is possessed by all contrasted experimental materials and most simples of Magnoliaceae in NCBI. So the new species was described and illustrated. Its floral buds cylindrical, ovaries subcordiform, and peduncles of flower and fruits obviously elongate are particular, which can be easily distinguished to the similar species and all other ones in the genus. The new species is distributed in Hengduan Mountain of west Yunnan province and south Xizang Autonomous Region at an altitude of 1900 3000 m, a colloquial name is Mulianhua, just as the similar species Y. campbellii. The designated type of the new species was collected from Baotai Mountain of Yongping County at altitude of $2600 \mathrm{~m}$ and kept at the Chinese Academy of Forestry. This paper will provide a new research method that can be easily verified for the evolutionary taxonomy and the new science of evolutionomy.
\end{abstract}

Keywords: PEL (Particularly Evolutionary Loci), Yulania Baotaina, trnL-ndhJ, Evolutionomy, New Species, Magnoliaceae

\section{Introduction}

As the most primitive taxa of Fructophyta D. L. Fu \& H. Fu [1], Yulania Spach [2-10] has a very important position and plays an important role in the evolutionomy of fruit plants. The large and beautiful early spring flowers of Yulania Spach were also deeply impressed and loved by the world's gardeners. For example, Yulania campbellii (Hook. f. et Thoms.) D. L. Fu (Magnolia campbellii) [2-6, 8-14], native to a wide area of the Himalayan region, such as E Nepal, Bhutan,
N India, Burma, and Xizang Autonomous Region and Yunnan province of China, had attracted admirations from horticulturists in the world, just as that D. Hunt had written "A variable species, spectacular in bloom" [11], and that D. J. Callaway had written "This species is often considered by writers and gardeners to be the most spectacular of all magnolias, and the most desirable" [12]. In the investigation of the plant resources of Yulania Spach, a new species, named Yulania baotaina, was found by the authors. It is very similar to the most spectacular and most desirable species, Y. 
campbellii (Hook. f. et Thoms.) D. L. Fu. In order to determine its evolutionary taxonomic status, the new species and the similar species were collected from Yunnan province and Xizang Autonomous Region of China, and the partial sequences of chloroplast genome, $\operatorname{tr} n \mathrm{~L}-n d h \mathrm{~J}$, were amplified and sequenced respectively. The partial sequences were analyzed and compared with 39 samples of the chloroplast complete genomes of Magnoliaceae in the NCBI (National Center for Biotechnology Information, USA) database, and the results are as follows.

\section{Materials \& Methods}

\subsection{Plant Materials}

Seven samples of the leaves of two similar species were collected from China: two of the new species of Yulania baotaina from Mountain Baotai in Yongping County of Yunnan province, five of the similar species Yulania campbellii (Hook. f. et Thoms.) D. L. Fu from Yongping and Gongshan County of Yunnan province and Yadong county of Xizang Autonomous Region respectively (see Table 1).

Table 1. Experimental materials of Magnolia sect. Rytidospermum.

\begin{tabular}{llll}
\hline Species & Experimental material & Samples & Collected place \\
\hline Yulania baotaina & leaves & 2 & Yongping, Yunnan, China \\
Y. campbellii & leaves & 1 & Yongping, Yunnan, China \\
Y. campbellii & leaves & 2 & Gongshan, Yunnan, China \\
Y. campbellii & leaves & 2 & Yadong, Xizang, China \\
\hline
\end{tabular}

Table 2. The designed primers for amplification and sequencing of partial cpDNA of Yulania.

\begin{tabular}{lll}
\hline Primer name & Primer sequences & Length of amplification and sequencing /bp \\
\hline \multirow{2}{*}{$t r n L-n d h J_{-} Y 01$} & F: 5'- TTTAGAAATCGTGAGGGTTCAAGTC-3' & 980 \\
\hline
\end{tabular}

Table 3. Contrasted chloroplast genomes of Magnoliaceae in NCBI.

\begin{tabular}{llll}
\hline Species & DNA number in NCBI & Species & DNA number in NCBI \\
\hline Liriodendron chinense & NC030504.1 & Magnolia pyramidata & NC023236.1 \\
Liriodendron tulipifera & DQ899947.1 & Magnolia sinica & NC023241.1 \\
Magnolia aromatica & NC037000.1 & Magnolia tripetala & NC024027.1 \\
Magnolia conifera & NC037001.1 & Magnolia yunnanensis & NC024545.1 \\
Magnolia dandyi & NC037004.1 & Michelia cathcartii & NC023234.1 \\
Magnolia dealbata & NC023235.1 & Michelia laevifolia & NC035956.1 \\
Magnolia duclouxii & NC037002.1 & Michelia odora & NC023239.1 \\
Magnolia fordiana var. calcarea & MF990562.1 & Michelia sp. & KY921716.1 \\
Magnolia glaucifolia & NC037003.1 & Yulania acuminata & JX280391.1 \\
Magnolia grandiflora & JN867584.1 & Yulania biondii & KY085894.1 \\
Magnolia grandiflora & JN867587.1 & Yulania denudata & JN227740.1 \\
Magnolia grandiflora & NC020318.1 & Yulania denudata & JN867577.1 \\
Magnolia insignis & MF990566.1 & Yulania denudata & JX280394.1 \\
Magnolia kwangsiensis & HM775382.1 & Yulania diva? & NC023242.1 \\
Magnolia officinalis & JN867579.1 & Yulania kobus & NC023237.1 \\
Magnolia officinalis & JN867581.1 & Yulania liliiflora & NC037005.1 \\
Magnolia officinalis & JN867582.1 & Yulania liliiflora & NC023238.1 \\
Magnolia officinalis & KY085916.1 & Yulania liliiflora & JX280397.1 \\
Magnolia officinalis & NC020316.1 & Yulania salicifolia & NC023240.1 \\
Magnolia officinalis var. biloba & JN867580.1 & & \\
\hline
\end{tabular}

\subsection{PCR Primer Design}

A pairs of primers, $t r n \mathrm{~L}-n d h \mathrm{~J}-\mathrm{Y} 01-\mathrm{F}$ and $t r n \mathrm{~L}-n d h \mathrm{~J}-\mathrm{Y} 01-\mathrm{R}$ were designed using Primer Premier 6, the sequences of primers and the length of amplification and sequencing of cpDNA, see Table 2 .

\subsection{PCR Amplification}

Total genomic DNA was isolated from silica-dried leaves of 7 materials belong to 2 species, 2 samples of Y. baotaina and 5 of Y. campbellii, using a modified CTAB method [15]. The primers of PCR amplification are trnL- $n d h \mathrm{~J}$ _Y01 (see Table 2). PCR amplifications were performed in $15 \mu \mathrm{L}$ volume containing $0.2 \mu \mathrm{L}$ forward primer and $0.2 \mu \mathrm{L}$ reverse primer, $1 \mu \mathrm{L}$ genomic DNA, $7.5 \mu \mathrm{L} 2 \mathrm{x}$ Es Taq MasterMix, $6.1 \mu \mathrm{L}$ $\mathrm{ddH}_{2} \mathrm{O}$, and with the following cycles: $5 \mathrm{~min}$ initial denaturation at $94^{\circ} \mathrm{C} ; 10$ cycles of $30 \mathrm{~s}$ at $94^{\circ} \mathrm{C}, 45 \mathrm{~s}$ at $61^{\circ} \mathrm{C}$ and $2 \mathrm{~min}$ at $72^{\circ} \mathrm{C} ; 27$ cycles of $30 \mathrm{~s}$ at $94^{\circ} \mathrm{C}, 45 \mathrm{~s}$ at $56^{\circ} \mathrm{C}$ and $2 \mathrm{~min}$ at $72^{\circ} \mathrm{C}$; and $5 \mathrm{~min}$ final extension at $72^{\circ} \mathrm{C}$. All PCR reactions were performed in T-gradient (Biometra). The amplified products of PCR were extracted and purified with the Gel Extraction Kit (OMEGA). 


\subsection{DNA Sequencing}

The purified DNAs were sequenced using ABI 3730 XL. The PCR amplifications were performed in $15 \mu \mathrm{L}$ volume containing $0.2 \mu \mathrm{L}$ forward primer and $0.2 \mu \mathrm{L}$ reverse primer, $1 \mu \mathrm{L}$ purified DNA, $7.5 \mu \mathrm{L} 2 \mathrm{x}$ Es Taq MasterMix, $6.1 \mu \mathrm{L}$ $\mathrm{ddH}_{2} \mathrm{O}$, and with the following cycles: $3 \mathrm{~min}$ initial denaturation at $95^{\circ} \mathrm{C}$; and 26 cycles of $10 \mathrm{~s}$ at $95^{\circ} \mathrm{C}, 10 \mathrm{~s}$ at $50^{\circ} \mathrm{C}$ and 4 min at $60^{\circ} \mathrm{C}$.

\subsection{DNA Sequence Analysis}

The partial correct sequences of absolutely coincident sequencing using the forward primer and reverse primer were analyzed. The particularly evolutionary loci could be easily found out and verified using some software such as Microsoft Word. The contrasted chloroplast complete genomes of Magnoliaceae in the NCBI database see Table 3.

\section{Two PEL (Particularly Evolutionary Loci) of cpDNA of Yulania Baotaina}

There are $810 \mathrm{bp}$ absolutely coincident sequences of Yulania baotaina, using the forward primer and reverse primer of trnL-ndhJ_Y01 respectively, which can be regarded as the correct partial cpDNA sequence of the new species. The sequence is as follow:

Yulania baotaina, partial sequence of $t r n \mathrm{~L}-n d h \mathrm{~J}$ of cpDNA TTCTCATTCACTCTACTCTTTCACAAATGGGTCCGA CCATAAATGTTTCTCTCTTATCACAAGTCTTGTGATAG ATATGATATACGTACAAATGCCCATATTATGGGCAAGG AATCTCCATTATTGAATCATTCACAGTGCATATCATTA CTCTTACACTTACAAAGCCTTCTTTTTGAAGATCCAA GAAATTCCAGGACCTAGGTAAGATTTTGGAATGCAA TTTGAGTCCCTTTAATTGACATAGACCCAAGTCCTCT AGTAGGATGACGCATCGGGAATGGTCGGGATAGCTC AGCTGGTAGAGCAGAGGACTGAAAATCCTCGTGTCA CCAGTTCAAATCTGGTTCCTGACACGTGGTTAATGTA TCAAACGGATACTCATACAAATGAATCGATATGGATC GGGATCCATATTTATTAATAGACTAATAGTCTAGACCA TGATACATAAGTCTAGACCATGATACATACTTATCCAT CTAGGTATATAAATGGATACCTCCCTTTTTGTAGATGG GTAAAGAATATATGGGTAAGGTAAAGAAAAGAATTA GATTCTATTCCCTCTTCTTTTTTGTTTGTTTATACTGTA CCTCCTCTCGCTCAAAAAGAATGTTAATACTTCATAC ATATCCGAAGTTAGTTGGCTTGGCTGAAAAACCCAA AAGTCTAGTCTAGAGGAGTGGAAGGATAGGAATAGA CAGGATTCATTTCAGATACAATACAAAGAAAGAAAA TCCGATCCCTTTTCATTTTCATTTCGGAATTTCÉTATT TTCTTTCATATTCTATTTCTTCACTTTCTATT

Compared to its similar species, Y. campbellii, and the other DNA data of Magnoliaceae in the NCBI database, it can be concluded that the evolutionary loci $t r n \mathrm{~L}-n d h \mathrm{~J}$ (...TTTCATTTCGGAATTTCCETATTTTCTT...) is particular because the loci are not synchronously possessed by all contrasted experimental materials and the chloroplast complete genomes in the NBCI database. The oppositely evolutionary loci of

transversions

$\operatorname{trn} \mathrm{L}-n d h \mathrm{~J}$

(...TTTCATTTCTGAATTTCATATTTTCTT...) is possessed by all experimental materials of the similar species, and most referenced chloroplast complete genomes of Magnoliaceae in NCBI, except some samples of other genera including one sample of species of Michelia L. (misidentified as Magnolia insignis_KY921716.1 in NCBI) with the mixed loci trnL-ndhJ (...TTTCATTTCGGAATTTCATATTTTCTT...), two samples of Liriodendron L. (L. chinense_NC030504.1 and L. tulipifera_DQ899947.1) with the other transition or transversion of second loci as trnL-ndhJ (...TTTCATTTCTGAATTTCATATTPTCTT...) (P=A, C), and two samples of Magnolia L. (M. yunnanensis_NC024545.1 and M. sinica_NC023241.1) with the other transition of the second locus as (...TTTCATTTCTGAATTTCATATTTTTTT...).

So, the new species, Yulania baotaina, is supported by cpDNA evolutionomy based on the evolutionary continuity principle [1] and the evolutionary particularity principle, for that it has at least two PEL of cpDNA trnL-ndhJ (...TTTCATTTCGGAATTTC트ATTTTCTT...). According International Code of Botanical Nomenclature [16], the new species should be described and illustrated.

\section{Yulania Baotaina D. L. Fu, Q. Zhang et M. Xu, sp. Nov., Figure 1}

Arbor decidua usque ad $30 \mathrm{~m}$ alta. Ramuli crassi annotini pallide virides vel flavo-virides nitidi sub glabri, hornotini nitidi subglabri, lenticellis albis rotundis; rumulis abbreviates dense 3-nodis, crassis, dense pallide flavo-villosis. Gemmae foliiferae cylindricae $1.8 \sim 3.6 \mathrm{~cm}$ longae et $0.4 \sim 0.8 \mathrm{~cm}$ diam. virides vel flavor-virides in sicco extus sparse pallide flavo-villosae. Alabastra solitaria terminalia cylindrica $7.0 \sim 8.0 \mathrm{~cm}$ longa et $1.5 \sim 2.0 \mathrm{~cm}$ diam. extus pallide flavo-villosa. Folia alterna subcoriacea longe elliptica $15.0 \sim 23.0 \mathrm{~cm}$ longa et $7.5 \sim 11.5 \mathrm{~cm}$ lata apice acuminata basi rotundata margine integra supra viridia glabra nitida subtus pallide viridia, dense pallide albo-tomentosa, costis et nervis lateralibus dense villosis, nervis lateralibus 11 17-jugis, petioli crassi $35 \sim 4.5 \mathrm{~cm}$ longi dense albo-villosi, cicatricibus stipularum ca. $6 \sim 12 \mathrm{~mm}$ longis longitudine 1/5 1/4 petiolorum partem aequantibus. Flores ante folia aperti, grandes diam. 20.0 25.0 cm; pedicelli robusti $3.3 \sim 4.1 \mathrm{~cm}$ longi et1.0 1.2 cm diam. glabri vel sparse villosi apice saepe sparse villosi; tepala 12 in quoque flore, petaliformia subsimilia, elliptica vel oblonga, $10.0 \sim 12.5 \mathrm{~cm}$ longa et $4.0 \sim 5.0 \mathrm{~cm}$ lata purpureo-rubra extus basi atro-purpurea ad purpureo-brunnea, intus pallida in colore; stamina numerosa $2.6 \sim 3.2 \mathrm{~cm}$ longa, filamentis $0.8 \sim 1.2 \mathrm{~mm}$ longis atro-purpureo-rubris, thecis lateribus longitudinali-dehiscentibus, connetivis apice cum mucronibus triangulis; gynoecium cylindricum3.2 3.7 cm longum purpureo-brunneum, pistillis simplicibus numerosis, ovariis subcordiformibus purpureo-brunneis sparse albo-pubescentibus, stylis et stigmatibus purpureo-rubris. Folliceta cylindrica $10.0 \sim 14.0 \mathrm{~cm}$ longa et $2.0 \sim 3.0 \mathrm{~cm}$ diam. atro-rubra apice saepe conica curvata; pedicelli fructiferi robusti $3.5 \sim 4.5 \mathrm{~cm}$ longi et 
$1.2 \sim 1.3 \mathrm{~cm}$ diam. apice sparse villosi.

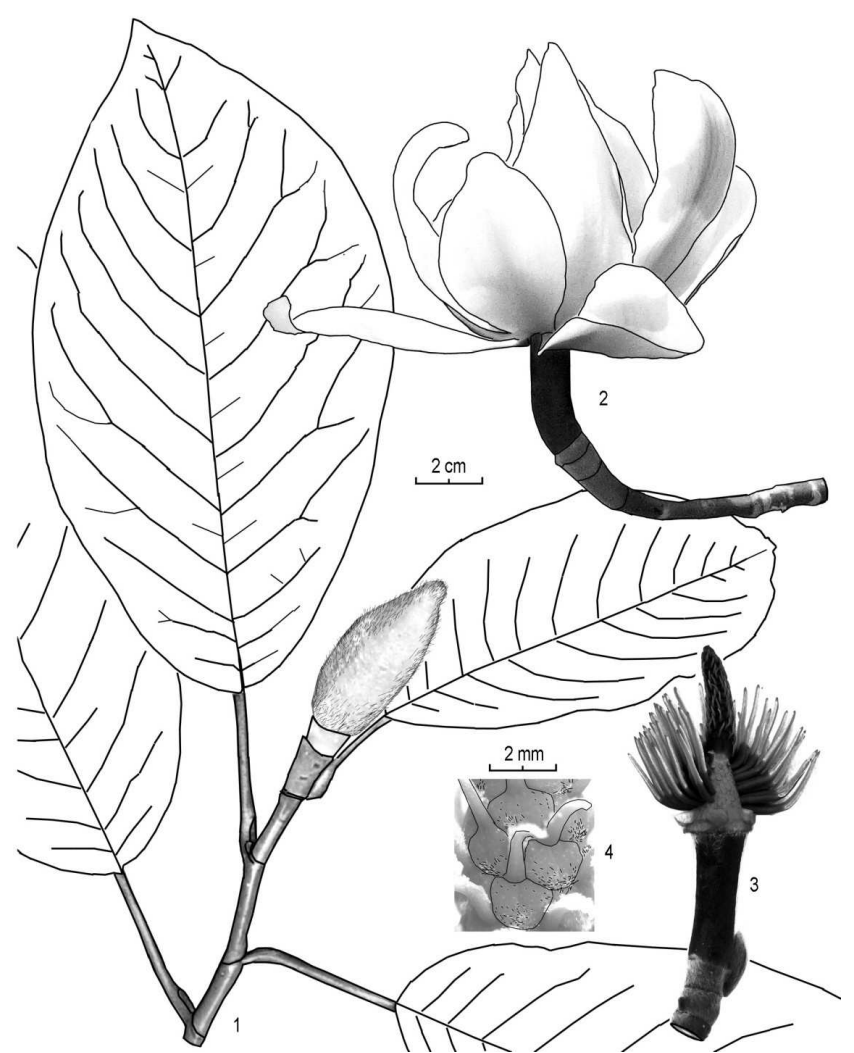

Figure 1. Yulania baotaina D. L. Fu, Q. Zhang et M. Xu, sp. nov. 1. branchlet with leaves and floral bud. 2. flower. 3. flower with tepals removed to show gynoecium and androecium. 4. part of gynoecium to show the shape and pubescences of ovaries (drawn by D. L. Fu)

Typus: The holotype D. L. Fu 2018031201 (Holotypus hic designatus, CAF) was branchlets with flower collected from Mountain Baotai, Yongping county, Yunnan province at alt. $2600 \mathrm{~m}$ on Mar. 12, 2017, and the paratype D. L. Fu 2017093001 (Paratypus, CAF) was branchlets with fruit, floral bud and leaves, collected from the same position on Sept. 09, 2017.

The new species is similar to Yulania campbellii (Hook. f. \& Thoms.) D. L. Fu, but its foliar buds were yellowish-green when dried, floral buds cylindrical and villous; ovaries subcordiform, purplish-brown and sparse pubescent at the bases, peduncles of flowers and fruits obviously elongate, are different from the latter's that foliar buds black-brown when dried, floral buds ovoid and long villous; ovaries rectangular, yellowish-green and glabrous, peduncles of flower and fruits not elongate. Floral buds cylindrical, ovaries subcordiform, peduncles of flowers and fruits obviously elongate are also the particular characters of the new species which can be easily distinguished to all other ones in the genus. The particularly evolutionary loci of the new species are trnL- $n d h \mathrm{~J}$ (...TTTCATTTCGGAATTTCㅡTATTTTCTT...).

The new species distributed in Hengduan Mountain of west Yunnan province and south Xizang Autonomous Region at an altitude of 1900 3000 m. Flowering March-April and fruiting September-October. The colloquial name is Mulianhua, just as the similar species Yulania campbellii (Hook. f. \& Thoms.) D. L. Fu.
The flowers of the new species are large, purple and colorful, and graceful. The floral buds are large and cylindrical, and the fruit is dark red and has various shapes. It is an excellent ornamental tree species. Floral buds are used in traditional Chinese medicine for "Xinyi" and are also the raw materials for extracting essence.

\section{Conclusion}

Yulania baotaina has at least two PEL of cpDNA, which are $t r n \mathrm{~L}-n d h \mathrm{~J} \quad$ (...TTTCATTTCG GAATTTCㅌTATTTTCTT...). Its floral buds cylindrical, ovaries subcordiform, and peduncles of flower and fruits obviously elongate are particular, which can be easily distinguished to the similar species and all other ones in the genus. So the new species is supported by cpDNA evolutionomy and morphological evolutionomy based on the evolutionary continuity principle and the evolutionary particularity principle, which provides a new research method that can be easily verified for the evolutionary taxonomy and the new science of evolutionomy.

\section{Acknowledgements}

This work was supported by the Fundamental Research Funds for the Central Non-profit Research Institution of CAF (CAFYBB2016MA009). All sequencing was done by Beijing Boyoushun Biotechnology Limited Corporation. We are grateful to Prof. Wencai Wang, the plant taxonomist and the academician of the Chinese Academy of Sciences, for his valuable suggestions and corrections in the Latin description. We thank Professor Junkai Gao of National Forestry and Grassland Administration, Suolang Wangdui of Department of Forestry of Xizang Autonomous Region and Jianbing Yue of Forestry Investigation and Planning Institute of Xizang Autonomous Region, and Engineers Yongxing Wang, Zhaowei Hou et al. of Forest Bureau of Yongping County, Xiaoyang He and Yun Xun of Forest Bureau of Gongshan County of Yunnan province, and Qin Zhao of Forest Bureau of Linzhi City, Pengfei Zhang of Forest Bureau of Motuo County, Laba Ciren et al. of Forest Bureau of Yadong County of Xizang Autonomous Region for the helps in the investigation of the plant resources.

\section{References}

[1] D. L. Fu and H. Fu. "An evolutionary continuity principle for evolutionary system of organism divisions". American Journal of Agriculture and Forestry, vol. 6, no. 3, pp. 60-64, 2018. DOI: 10.11648/j.ajaf.20180603.14.

[2] D. L. Fu. "Notes on Yulania Spach". Journal of Wuhan Botanical Research, vol. 19, no. 3, pp. 191-198, 2001.

[3] Z. Y. Wu, A. M. Lu, C. Y. Tang, Z. D. Chen, D. Z. Li. "A generality on the families and genera of Angiosperms in China". Beijing: Science Press, pp. 62-64, 2003.

[4] KIB (Kunming Institute of Botany). "Flora Yunnanica". vol 16. Beijing: Science Press, pp. 25-30, 2006. 
[5] G. H. Tian, D. L. Fu, D. W. Zhao, J. Zhao, T. B. Zhao. "Study on the Species Resources and New Classification System of Yulania Spach". Chinese Agricultural Science Bulletin, vol. 22, no. 5, pp. 404-411. 2006.

[6] N. H. Xia, Y. H. Liu, H. P. Nooteboom. "Magnoliaceae". In: Wu Z Y, P. H. Raven, Hong D Y. "Flora of China", Beijing: Science Press \& St. Louis, MO: Missouri Botanical Garden Press, vol. 7, pp. 71-77, 2008.

[7] N. H. Xia. "A New classification System of the Family Magnoliaceae". In: Xia N H, Zheng Q W, Xu F X, Wu Q G. Proceedings of the Second International Symposium on the Family Magnoliaceae. Wuhan: Huazhong University of Science \& Technology Press. pp. 12-38, 2009.

[8] T. B. Zhao, G. H. Tian, D. L. Fu, and D. X. Zhao. "Shijie Yulanshu Zhiwu Ziyuan yu Zaipei Liyong”. Beijing: Science Press, pp. 179-383, 2013. [in Chinese]

[9] T. B. Zhao, Z. F. Ren, and G. H. Tian. "Shijie Yulanshu Zhiwu Zhongzhi Ziyuan Zhi”. Zhengzhou: Yellow River Conservancy Press, pp. 1-153, 2013. [in Chinese]

[10] T. B. Zhao, L. H. Song, G. H. Tian, and Z. X. Chen. "Henan
Yulan Zaipei”. Zhengzhou: Yellow River Conservancy Press, 138-310, 2015. [in Chinese]

[11] D. Hunt. "Magnolias and their allies". Sherborne: International Dendrology Society and The Magnolia Society, pp. 104-126, 1998.

[12] D. J. Callaway. "The World of Magnolias". Portland: Timer Press, pp. 135-174, 1994.

[13] Agendae ASE (ed.). "Flora Reipublicae Popularis Sinicae", Tomus 30 (1). Beijing: Science Press, pp. 126-141. 1996.

[14] Y. H. Liu. "Magnolias of China". Beijing: Science Press, 44-55, 2004.

[15] N. Li., W. Huang, Q. Shi, Y. Zhang, and L. Song. "A CTAB-assisted hydrothermal synthesis of VO2 (B) nanostructures for lithium-ion battery application". Ceram. Int.vol. 39, pp. 6199-6206, 2013. DOI: 10.1016/j.ceramint.2013.01.039.

[16] G. H. Zhu (translator). "International Code of Botanical Nomenclature (St. Louis Code) ". Beijing: Science Press /St Louis, MO: Missouri Botanical Garden Press, pp. 1-100, 2001. 